\title{
Accuracy of Hemoglobin Measurement Using Noninvasive Oxyhemoglobinometer in Pregnant Women at Health Center of Bantul District
}

\author{
Ratih Devi Alfiana ${ }^{1}$, Hasballah Zakaria² ${ }^{2}$ M. Nurhalim Shahib ${ }^{3}$, Herman Susanto ${ }^{4}$ \\ ${ }^{1}$ Student of Midwifery Master's Program Faculty of Medical, University of Padjadjaran \\ ${ }^{2}$ School of Electrical Engineering and Informatics, Institute Technology of Bandung \\ ${ }^{3}$ Departemen Clinical Medicine Faculty of Medical, University of Padjadjaran \\ ${ }^{4}$ Department of Oncology, Obstetrics and Gynecology Faculty of Medical, University of Padjadjaran \\ Email : ratihdevialfiana@gmail.com
}

\begin{abstract}
Abstrak
Anemia defisiensi besi merupakan masalah kesehatan yang utama pada wanita hamil dan mempunyai efek yang merugikan pada ibu dan bayi baru lahir. Mengingat konsekuensi anemia selama kehamilan, diagnosis yang mudah dan akurat merupakan hal penting. Selama ini pengukuran kadar hemoglobin dengan cara melibatkan pengambilan darah secara invasif, sehingga menimbulkan ketidaknyamanan dan trauma tersendiri bagi pasien. Oleh karena itu, diperlukan alat ukur kadar hemoglobin dengan menggunakan sistem oksimeter secara noninvasif, di mana pasien akan terbebas dari rasa nyeri dengan risiko minimal mengalami infeksi dan memungkinkan untuk pemantauan pasien dalam keadaan kritis. Tujuan penelitian ini untuk membandingkan hasil kadar hemoglobin menggunakan alat oksihemoglobinometer dengan automated hematology analyzer sehingga diketahui perbedaan hasil, diperoleh nilai sensitivitas, spesifisitas, nilai duga positif, nilai duga negatif, rasio kemugkinan positif, rasio kemungkinan negatif, dan akurasi.

Penelitian ini merupakan uji diagnostik dengan desain cross sectional. Tujuh puluh delapan ibu hamil normal yang memeriksakan kehamilannya di Puskesmas wilayah Kabupaten Bantul, masing-masing dilakukan pemeriksaan kadar hemoglobin dengan menggunakan alat oksihemoglobinometer dan automated hematology analyzer sebagai pembanding. Untuk perbedaan hasilnya digunakan Uji t berpasangan, dan dengan rumus uji diagnostik diperoleh nilai sensitivitas dan spesifisitas.

Terdapat perbedaan antara alat oksihemoglobinometer dengan hasil rata-rata $12,2 \pm 1,7$ dan pada automated hematology analyzer diperoleh rata-rata $11,6 \pm 1,2$. Dengan nilai $p$ 0,001 yang artinya terdapat perbedaan yang signifikan terhadap kedua alat. Hasil analisis uji diagnostik didapatkan akurasi 69,2\%. Alat oksihemoglobinometer belum bisa digunakan sebagai alat ukur kadar hemoglobin secara akurat karena hasil akurasi dari alat yang masih rendah yaitu 69,2\%.
\end{abstract}

Kata kunci: oksihemoglobinometer noninvasif, diagnosis anemia, akurasi

Abstract
Iron deficiency anemia is a major health problem in pregnant women and has a detrimental
effect on mothers and newborns. Given the consequences of anemia during pregnancy, an
easy and accurate diagnosis is important. During this measurement of hemoglobin levels
by involves taking the blood invasively, causing discomfort and trauma for the patient.
Therefore, a hemoglobin level gauge is required using a non-invasive oxymeter system,
in which the patient will be free of pain with minimal risk of infection and allow for the
monitoring of the patient in critical condition. The purpose of this study was to compare
the results of hemoglobin concentration using an oxyhemoglobinometer with automated
hematology analyzer as gold standard to know the difference of result of accuracy. This 
study is a diagnostic test with cross sectional design. 78 normal pregnant women who checked their pregnancy at the center of health in Bantul district, each of them are examined their hemoglobin level by using the oxyhemoglobinometer and automated hematology analyzer as a comparison. For the different results were used pairwise $t$ test, and with diagnostic test formula obtained accuracy values. There is a difference between the oxyhemoglobinometer tool with the average of $12.2 \pm 1.7$ and in the automated hematology analyzer obtained an average of $11.6 \pm 1$.2. With a value of $p 0.001$ which means there is a significant difference between the two tools. The results of the diagnostic test analysis obtained an accuracy of $69.2 \%$. The oxyhemoglobinometer device cannot be used as an accurate measurement of hemoglobin levels, because the tool its low of accuracy.

Keywords: noninvasive oxyhemoglobinometer, diagnosis of anemia, accuracy

Article info:

Article submitted on March 01, 2018

Articles revised on March 15, 2018

Articles received on March 30, 2018

DOI: http://dx.doi.org/10.21927/jnki.2018.6(1).59-64

\section{INTRODUCTION}

Pregnancy influences a variety of physiological changes. One of the most significant changes is improvement volume so that hematocrit normally declines. This often results in the state of pregnant women experiences iron deficiency anemia.(1) Iron deficiency anemia is a major health problem in pregnant women and it has adversed effects on mothers and newborns. This affects about 1.62 billion people from the global population(2). The prevalence of anemia in India is $82 \%$ (3), Ethiopia is $56.8 \%$ (4). In Indonesia, the prevalence of anemia in pregnant women is $37.1 \%$ according to the data of Basic Health Research in 2013(5). In Yogyakarta the prevalence of maternal anemia increases in 2012 to 2013 , which is $17.35 \%$ to $17.60 \%$. The prevalence of pregnant woman's anemia in Bantul Regency is 27, 76\%(6). Iron deficiency anemia in pregnancy can result in harmful effects for the mother and fetus(7). Given the consequences of anemia during pregnancy, an easy and accurate diagnosis is important. Several methods are available for HB estimation in field settings, such as heavy copper sulphate type method, Lovibond comparator, HemoCue, Rapid test, Hemoglobin Color
Scale, Cyanmethemoglobin, and Automated Hematology Analyzer(2).

The key for detecting anemia is proper diagnosis and monitoring of hemoglobin levels. However, measurement of hemoglobin levels by involving invasive blood sampling may potentially pose a risk of infection in both health care and patients. This is a major challenge in areas where there is a lack of water, electricity, necessary hygiene infrastructure and skilled healthcare providers. Thus, noninvasive hemoglobin screening is expressed by the World Health Organization (WHO) as one of the key medical technologies for improving health globally(8). From the above problems, both in terms of technology, patient comfort and other factors, a hemoglobin level gauge is required using a noninvasive oxymeter system. Where the patient will be free from pain with minimal risk of infection and allow for patient monitoring in critical condition(9). The results of a study from Jung YH et al. entitled The efficacy of noninvasive hemoglobin measurements by CO-oximetry in neonates, Noninvasive $\mathrm{Hb}$ values measured by CO-oximeter oximeter significantly correlated with venous $\mathrm{Hb}$ levels (correlation coefficient, $r=0.758$; $\mathrm{p}<0.001$ ). The $\mathrm{Hb}$ value measured by the CO- 
oximeter oximeter was higher than that measured by the laboratory hematological analyzer (13.3 \pm $2.6 \mathrm{~g} / \mathrm{dL}$ vs. $12.5 \pm 3.1 \mathrm{~g} / \mathrm{dL})$. The conclusion is noninvasive $\mathrm{Hb}$ measurements with Pulse $\mathrm{CO}$ Oximetry provide clinically acceptable accuracy, and they significantly correlate with laboratory $\mathrm{Hb}$ measurements in neonates. In the case of clinical application, noninvasive $\mathrm{Hb}$ monitoring with CO-oximeter pulses can be useful in the early detection of $\mathrm{Hb}$ changes in neonates. accuracy is one of the parameters to measure the effectiveness of oxyhemoglobinometer compared to the automated hematology analyzer as the gold standard(20).

\section{MATERIALS AND METHOD}

This research is a diagnostic test with cross sectional design, which is the data retrieval for each subject is done in one unit of time(10). This research is to compare the result of hemoglobin content using new tool with gold standard so that the difference of the result is obtained the accuracy.

The subjects of this study are pregnant women at Health Center of Bantul District who fulfilled inclusion criteria, pregnant women who came to check their pregnancy at Health Center of Bantul Regency and pregnant mother who was willing to take blood for hemoglobin examination, and pregnant mother who do not use nail polish. The exclusion criteria of pregnant women who experience an emergency.

The primary data were collected from hemoglobin concentration from oxyhemoglobinometer and automated hematology analyzer. The data collection instrument in this study used a hemoglobin diagnostic tool consisting of an oxyhemoglobinometer and an automated hematology analyzer.

The data obtained from the two examination tools in the form of interval data will be known whether there is a significant difference between the results of the tool oxyhemoglobinometer with automated hematology analyzer. Before the bivariable analysis is done normality test, if normal test used is paired $\mathrm{P}$ test $\mathrm{T}$, if the data is not normal test used Wilcoxon. The validity of the oxymeter device is calculated based on the degree of accuracy. This research seeks to uphold the scientific attitude and is very concerned about ethics considering the subject of research is human. This research has applied 3 basic principles of research ethics, namely: Respect for persons, Beneficent and nonefficiency, Justice(11)(12).

The research was conducted in the area of Health Center of Bantul Regency which purposively random sampling was taken that is determining the Health Center in Bantul district as the location of respondent taking with consideration of Health Center using hemoglobin level measurement with automated hematology analyzer. Among other things, Health Center of Kasihan I, Kasihan II health center, Sedayu II health center, Sewon I community health center, Banguntapan I community health center.

\section{RESULT AND DISCUSSION}

\section{Result}

The characteristics of research subjects presented to determine the frequency distribution of respondent characteristics, can be seen in the following table 1.

From the table above, it can be seen that on gravida characteristic more multigravida $(71.8 \%)$ than primigravida $(28.2 \%)$. Characteristic age of pregnant mother dominant at healthy reproductive age that is $20-35$ years equal to $79.5 \%$. On the characteristics of trimester or pregnancy age in pregnant women more in trimseter II that is equal to $43.6 \%$. While on the characteristics of education, the dominant respondents of the research are high school graduates of $43.6 \%$.

The result of difference of result from oxyhemoglobinometer and Sysmex KN-21 can be seen in table below: 
Table 1. Respondent characteristics

\begin{tabular}{lcc}
\hline \multicolumn{1}{c}{ Characteristics } & $\begin{array}{c}\text { Frequency } \\
\mathrm{N}=78\end{array}$ & Persentage \\
\hline $\begin{array}{l}\text { Gravida } \\
\text { - Primi }\end{array}$ & 22 & $28.2 \%$ \\
- Multi & 56 & $71.8 \%$ \\
Age & & \\
- $\quad$ 20th & 2 & $2.6 \%$ \\
- 20-35th & 62 & $79.5 \%$ \\
- >35th & 14 & $17.9 \%$ \\
Trimester & & \\
- I & 20 & $25.6 \%$ \\
- II & 34 & $43.6 \%$ \\
- III & 24 & $30.8 \%$ \\
Education & & \\
- Elementary/Junior High & 19 & $24.4 \%$ \\
$\quad$ School & & \\
- Senior High School & 34 & $43.6 \%$ \\
- University & 25 & $32.1 \%$ \\
\hline
\end{tabular}

Table 2. The Difference result of Oxyhemoglobinometer and Sysmex KN-21

\begin{tabular}{lcc}
\hline & Mean & $\mathrm{p}$ \\
\hline Oxyhemoglobinometer & $12.2 \pm 1.7$ & \multirow{2}{*}{0.001} \\
Sysmex KN-21 & $11.6 \pm 1.2$ & \\
\hline
\end{tabular}

Note : *) Paired t test

From the table above can be seen that the value of $p$ obtained 0.001 , which means there is a difference of $\mathrm{Hb}$ levels between the oxyhemoglobinometer tool compared to Gold Standard Sysmex KN-21.

The results of the diagnostic test of the oxyhemoglobinometer tool compared with the automated hematology analyzer can be seen in the following table 3 .

From the table above, the researcher can analyze with the formula of accuracy $(a+d) /$ $\mathrm{N}=(4+50) / 78$ is $69.2 \%$.

\section{Discussion}

The principle of observation of hemoglobin and noninvasive blood oxygen content in the oxymeter system is the change in the color of the oxidized hemoglobin measured by the difference in absorption, when light is of a certain wavelength and penetrates tissue and blood. Blood containing oxygen-bound hemoglobin ( $\mathrm{HbO} 2$ / Oxyhemoglobin) with no $(\mathrm{Hb})$ will show different absorption spectra of light emission.

In this study, hemoglobin levels were examined in a non-invasive way or not by injury, ie light with a certain wavelength was transmitted across the probe and reached the detector / photodiode, then processed with a preprogrammed microcontroller so that the resulting hemoglobin levels were displayed on the LCD.

On developing tools using red and infrared LEDs. The wavelength on the red LED is $620 \mathrm{~nm}$ and the infrared LED is $940 \mathrm{~nm}$. Both LEDs act as transmitters and photodiodes as receivers. The LED transmits light through the blood vessels and the photodiode receives the output from both LEDs which can be used to calculate the percentage of oxygen concentration. Appropriate wavelengths are selected for the relative analysis of changes in hemoglobin levels. Both wavelengths are chosen because the oxygencontaining hemoglobin absorbs the wavelength of $910 \mathrm{~nm}$ light and the hemoglobin-induced hemoglobin that absorbs oxygen absorbs the $650 \mathrm{~nm}$ wavelength.

This research is in line with the research design entitled "Design of Measuring Tools of

Table 3. The Oxyhemoglobinometer Diagnostic Test compared to Sysmex KN-21

\begin{tabular}{llccc}
\hline & & \multicolumn{2}{c}{ Sysmex KN-21 } & Total \\
\hline & & Anemia & Not Anemia & \\
\hline \multirow{2}{*}{ Oxyhemoglobinometer } & Anemia & $4(17.4 \%)$ & $19(82.6 \%)$ & 23 \\
Total & Not Anemia & $5(9.1 \%)$ & $50(90.9 \%)$ & 55 \\
\hline & & 9 & 69 & 78 \\
\hline
\end{tabular}

Note : *) Diagnostic Test 
Hemoglobin Level, Oxygen Content and Sugar Level in Human Blood Non-invasive Based on Microcontroller". The realization of the design result of the tool can measure by $0-0.250 \mathrm{mg} /$ dl for sugar content, 0-20 gr / dl for hemoglobin, and $0-100 \%$ for oxygen content in blood(17).

In the selection of red LED color is also in line with research conducted by Guruh and firends entitled " The Design of Building MicrocontrollerBased Microcontroller ATMega16", the results of his research that red LEDs are better to break through the organ network of fingers. 48

On examination of the tool researchers using the index finger, this is in line with the results of the research entitled "Design of Measure Measures Hemoglobin and Oxygen in Blood with the Sensor of Oxymeter Non-invasive", which concluded that the most accurate finger for measurement is the index finger because the index finger has the finger size corresponding to the oxymeter sensor.23

The results of the oxyhemoglobinometer showed that the accuracy were still low, its $69,2 \%$. This could be due to several factors below: 1) Bright light (such as indoor lights or sunlight) directly on the probe can affect the reading. This is in line with the results of a study entitled 'Potential errors in pulse oxymetry', it is the external light source influences the reading, with the result decreasing from $97 \%$ to $93 \%$. The researchers recommend the use of fabric or rubber-wrapped fabrics wrapped around the probe to reduce external light to reach the light detector.55,59 In this study the factor has been controlled by means of a probe protected by an opaque material; 2) Movement can make difficulty for probe in taking signal. In this study the factors were controlled by asking respondents not to talk and move during the test.59; 3) Pulse oxymeter works well when all light passes through arterial blood. However, if the probe is wrong or not properly applied, some light does not pass through the arteries or travel on the side of the artery (shunting). It will reduce the pulsed signal strength making the pulse oxymeter vulnerable to errors. Therefore it is important to select the probe of the correct size so that the finger placement is right for best results. In this study researchers used a probe that conforms to the standard for oxygen saturation checks.57; 4) Pulse oxymeter only detects pulsed flow. When blood pressure is low due to hypovolemic shock or low cardiac output or the patient has arrhythmias, the pulse may be very weak and the oxymeter may not be able to detect the signal.59; 5) Vasoconstriction can reduce blood flow to peripheral, this causes the oxymeter may fail to detect the signal if the patient is very cold (chills) .59; 6) Poisoning can give high false saturation readings. Carbon monoxide binds hemoglobin and displaces oxygen to form a bright red compound called carboxyhaemoglobin. This can occur in patients who breathe smoke from fire.57,59; 7) Pulse oxymeter cannot distinguish between different forms of hemoglobin. Carboxyhaemoglobin (hemoglobin combined with carbon monoxide) is listed as $90 \%$ oxyhemoglobin and $10 \%$ deoxyhemoglobin. The presence of methaemoglobin will prevent the oxymeter from working accurately and the reading will tend toward $85 \% .58$; 8) Nail polish can cause inaccurate readings. It based on the results of a study entitled "Effects of nail polish on oxygen saturation determined by pulse oxymetry in critically ill patients", suggesting researchers to remove nail polish to help reduce measurement errors.56 This factor is controlled by researchers by inserting into the criteria inclusion of respondents.

From the analysis of several factors causing inaccurate readings of the above pulse oxymeter, and only a few that can be controlled by the researchers, it is possible to be the cause of the low validity of the oxyhemoglobinometer tool in this study. 


\section{CONCLUSION AND RECOMMENDATION}

There is difference result between tool of oxyhemoglobinometer and automated hematology analyzer (Sysmex KN-21) in checking hemoglobin level in pregnant woman at Health Center area of Bantul district of Yogyakarta with value $p=$ 0,001 . The oxyhemoglobinometer device cannot be used as a measure of hemoglobin levels accurately because of the low validity of the tool, it is accuracy $69.2 \%$.

\section{REFERENCES}

1. Cunningham L, Bloom, Hauth, Rouse, Spong. Obstetri Williams. 23 ed. Jakarta: EGC; 2013. $1138 \mathrm{p}$

2. Bala V, Shukla, Tiwari, Bhatt, Gupta. Validity and Realiability of Haemoglobin Colour Scale and its Comparison with Clinical Signs in Diagnosing Anaemia in Pregancy in Ahmedabad, India. Eastern Mediterranean Health Journal. 2012;18

3. Dutta S. Correlates Of Anaemia And Worm Infestation Among Rural Pregnant Women: A Cross Sectional Study from Bengal. National Journal of Community Medicine. 2013;4(4).

4. Alene D. Prevalence of Anemia and Associated Factors among Pregnant Women in an Urban Area of Eastern Ethiopia. Hindawi Publishing Corporation. 201425 Agustus;2014

5. (RISKESDAS) RKD. 2013.

6. Kesehatan D. Bantul D.I. Yogyakarta: 2013.

7. Soemantri S RL, Budiarso. Survei Kesehatan Rumah Tangga (SKRT). Jakarta: Badan Penelitian dan Pengembangan Kesehatan, 1995.

8. Ma'ayan L. Non-invasive hemoglobin screening for diagnosis and monitoring of anemia.

9. Doshi R. Optical sensor system for hemoglobin measurement. International Journal of Computational Engineering Research. 2013;03(7):41-5.

10. Sopiudin DM. Penelitian Diagnostik: Dasardasar teoretis dan aplikasi dengan program
SPSS dan Stata. Jakarta: Salemba Medika; 2009.

11. S A. Prosedur Penelitian: Suatu pendekatan praktik. revisi ed. Jakarta: PT Rineka Cipta; 2010.

12. Satari MH WF. Konsistensi penelitian dalam bidang kesehatan. Cetakan pertama ed. Bandung: Refika Aditama; 2011.

13. P S. IImu Kebidanan. Jakarta: Yayasan Bina Pustaka; 2009.

14. IM B. Hematologi Klinik Ringkas. Jakarta: EGC; 2006.

15. Irianti H, Duhita, Prabandari, Yulita, Yulianti, Hartiningtyaswati, Anggraini , CV. Sagung seto: Jakarta, ISBN: 987-602-271-015-8, 2013. Asuhan Kehamilan Berbasis Bukti : Paradigma Baru Dalam Asuhan Kehamilan. 1 ed. Jakarta: Sagung seto; 2013.

16. Patil Dr Prashant T, Patil Dr Sarika. Variability and Accuracy of Sahli's Method in Estimating of Haemoglobin Concentratuon. NIJIRM. 2013;4(1).

17. Akhtar S, Rahman, Hasan, Shahid. 24(4):170-172. HemoCue photometer: a better alternative of hemoglobin estimation in blood donors? Indian J Hematol Blood Transfus. 20084 Juni 2008;24(4):170-2. Epub 7 November 2008.

18. CJaBI. Haemoglobin colour scale for anaemia diagnosis where there is no laboratory: a systematic review. International Journal of Epidemiology. 2005 (34):1425-34. Epub 30 September 2005.

19. Aldridge F, Albonico, Ame, Montresor. Evaluation of the diagnostic accuracy of the Haemoglobin Colour Scale to detect

20. Jung $\mathrm{YH}$, Lee J, Kim HS, Shin SH, Sohn JA, Kim EK, Choi JH. The efficacy of noninvasive hemoglobin measurements by CO-oximetry in neonates. Pediatric Child Care Medicine. 14 (1): 70-73. January 2013. 